\title{
Akibat Hukum serta Sanksi Pemalsuan yang Dilakukan Notaris Kepada Penghadap Ketika Pembuatan Akta Otentik
}

\author{
Ni Made Lalita Sri Devi ${ }^{1}$, I Ketut Westra ${ }^{2}$
}

${ }^{1}$ Fakultas Hukum Universitas Udayana, E-mail: lalitands@yahoo.com

${ }^{2}$ Fakultas Hukum Universitas Udayana, E-mail: ketutwestrafh@gmail.com

\begin{abstract}
Info Artikel
Masuk: 27 Februari 2021

Diterima :22 Juni 2021

Terbit: 1 Juli 2021

Keywords :

Data Falsification, Notary,

AuthenticDeed.

Kata kunci: Pemalsuan Data, Notaris, Akta Otentik.

Corresponding Author: Ni Made Lalita Sri Devi, E-mail:lalitands@yahoo.co.id DOI:

10.24843/AC.2021.v06.i02.p03
\end{abstract}

\begin{abstract}
This study was intended to give an understanding regarding Notary responsibility arrangements of the Notary who commits violation in carrying out the position as well as provides legal protection that is obtained by the party against the data falsification by a Notary. The research of this normative law examined the norm that happens, such as a norm vacuum that does not regulate criminal sanctions in Laws of Notary. This research contained several sources, such as premier, secondary, and tertiary laws. Furthermore, the research approach was done by the conceptual approach that analyzes the concept of organizing violations by the notary. The result of this research was the Notary deed can be requested for the deed to be annulled based on the legally binding decisions determined by the District Court, then, the Notary Deed can be disqualified and can be avowed as the non-binding deed for the parties who made it. The sanctions of the Notary who falsified the data in making the authentic deed are, administrative sanction or the notary code of ethics, the sanction based on The Civil Law Code, and the sanction based on Criminal Code. The Notary can also be sued for compensation if the violation that is done by the notary causes a deed becomes an inauthentic deed and be relegated to the deed for who made it. This is the protection that can be given to the party if a Notary does not carry out the duties and obligations.
\end{abstract}


membuatnya. Adapun sanksi bagi Notaris yang melakukan pemalsuan data dalam pembuatan akta otentik ialah sanksi administratif atau Kode Etik Notaris, sanksi menurut hukum KUH Perdata, sanksi menurut KUH Pidana. Notaris jugadapat digugat ganti rugi apabila pelanggaran atau kesalahan yang dilakukan Notaris mengakibatkan suatu akta menjadi tidak otentik dan terdegradasi menjadi akta di bawah tangan. Inilah bentuk perlindungan yang diberikan kepada penghadap jika seseorang Notaris tidak melaksanakan tugas dan kewajibannya.

\section{Pendahuluan}

Notaris merupakan suatu profesi yang juga menempati posisi sebagai pejabat umum. Dalam posisinya sebagai profesional di bidang hukum, Notaris berperan dalam menciptakan kepastian hukum bagi masyarakat dalam rangka penegakan hukum. Notaris merupakan suatu profesi yang tercipta secara tidak langsung dari hasil interaksi antar masyarakat yang kemudian berkembang dalam memenuhi kebutuhan masyarakat itu sendiri. Peran Notaris sebagai ranah pencegahan (preventif) agar tidak terjadi permasalahan hukum dilakukan dengan adanya akta otentik yang merupakan alat bukti kekuatan pembuktian yang sempurna, dapat memberikan kontribusi nyata dalam penyelesaian sengketa apabila terjadi di kemudian hari. "Akta ialah tulisan yang memang sengaja dibuat untuk dapat dijadikan suatu alat bukti apabila akta dibuat oleh dan di hadapan Notaris maka akta tersebut dapat dikatakan sebagai akta notarial atau akta otentik atau akta Notaris". Akta dapat disebut otentik jika dibuat dihadapan pejabat yang berwenang. Berdasarkan "Pasal 1 angka 1 Undang-undang No 2 Tahun 2014 tentang Perubahan Atas Undang-undang No 30 Tahun 2004 tentang Jabatan Notaris" (selanjutnya di singkat UUJN) "Notaris adalah sebagai pejabat umum yang berwenang untuk membuat akta otentik dan memiliki kewenangan lainnya sebagaimana dimaksud dalam Undang-Undang ini." Kedudukan terpenting Notaris pada hubungan hukum dikehidupan masyarakat disebabkan berisi pembuktian tertulis yang wujud akta yang otentik.

Pejabat umum merupakan seseorang yang mengemban suatu jabatan, yang kemudian diangkat serta diberhentikan negara, yang diberikan wewenang dan kewajiban agar dapat memenuhi kepentingan anggota masyarakat di bidang hukum keperdataan. Maka dari itu Notaris merupakan suatu organ negara yang dimana negara memberikan wewenang kepada Notaris melalui ketentuan dalam UUJN, untuk membuat suatu akta yang otentik. Notaris selaku pejabat umum yang memiliki wewenang dalam sebagian tugas kenegaraan, bukan sekedar bekerja untuk kepentingannya sendiri, melainkan juga dituntut untuk dapat bertanggung jawab memenuhi kebutuhan akan pelayanan dan jasa kepada masyarakat terkait dengan perbuatan hukum perdata.

Notaris dalam melaksanakan tugas dan jabatannya dituntut wajib mandiri, tidak bergantung kepada orang lain, tak memandang status sosial atau derajat seseorang dan memiliki kebebasan karena berdiri sendiri (unpartiality and Independency). ${ }^{1}$ Notaris

${ }^{1}$ Rositawati, D., Utama, I. M. A., \& Kasih, D. P. D. (2017). Penyimpanan Protokol Notaris secara Elektronik dalam Kaitan Cyber Notary. Acta Comitas: Jurnal Hukum Kenotariatan, 2(2), 172-182. h.175. doi: https:// doi.org/10.24843/AC.2017.v02.i02.p01 
membuat akta tidak berdasarkan keinginan diri pribadi, melainkan berdasarkan atas kehendak bebas dari para pihak yang memiliki kepentingan. Notaris ditugaskan untuk mengkonstatir semua keterangan dan pernyataan yang diberikan kepadanya terkait dengan hal dihendaki dan diinginkan para pihak yang bersangkutan. Akta yang dibuat mencakup hal-hal terkait semua perbuatan atau perjanjian yang ditugaskan kepada Notaris berdasarkan peraturan perundang-undangan. ${ }^{2}$

Seperti kasus mengenai seorang Notaris di Lhoksumawe yang bernama Immran Zubir Daoed, S.H, menuliskan keterangan data palsu pada akta otentik yang dibuatnya. Kasus ini diputus Pengadilan Negeri Lhoksumawe Nomor 40/Pid.B/2013/PN.Lsm, 29 April 2013. Amar putusan PN Lhoksumawe ini menyebutkan Notaris terbukti bersalah secara resmi karena melanggar tindak pidana pemalsuan, selanjutnya PN Lhoksumawe memberikan hukuman pidana penjara 2 bulan. ${ }^{3}$

Meninjau melalui UUJN, tindakan yang dilanggar Notaris mengenai prosedur pembuatan akta otentik sebagaimana pada aturan UUJN, Pasal 16 ayat (1) huruf a UUJN "Notaris wajib bertindak jujur, saksama, mandiri, tidak berpihak dan menjaga kepentingan pihak yang terkait dalam perbuatan hukum", tetapi UUJN tak ada penjelasan signifikan terkait "bertindak jujur, saksama, mandiri". Selama pada ketentuan Notaris harus melindungi kepentingan pihak-pihak mengenai perbuatan hukum diartikan penghadap yang bersangkutan pada pembuatan akta harus dapat perlindungan hukum.

Ketentuan tersebut tentu mampu dikembangkan lagi bahwasanya fungsi pejabat umum yaitu Notaris mempunyai kewenangan membuat sesuatu yang disebut akta otentik yang memiliki ketersinggungan terhadap segala perbuatan, perikatan, perjanjian, dan segala ketetapan dan kesemuanya itu telah ditetapkan dalam hukum positif. Penjelasan terhadap akta autentik telah dimuat Pasal $1868 \mathrm{KUH}$ Perdata menentukan "akta otentik ialah suatu akta yang dibuat dalam bentuk yang ditentukan Undang-undang oleh atau dihadapan pejabat umum yang berwenang untuk itu di tempat akta itu dibuat".

Hukum tak bisa dipisahkan dari kehidupan masyarakat selalu mempunyai aturan hukum yaitu ada masyarakat ada norma hukum. Tata hukum mengacu kepada perlindungan untuk semua martabat manusia, hukum selalu mengatur kepentingankepentingan serta keseimbangan guna mencegah terjadinya konflik permasalahan. Adanya hukum untuk melakukan keseimbangan antara hak-hak perorangan maupun bersama, dengan demikian secara dasar hukum wajib adil serta pasti guna dapat berfungsi dengan baik. ${ }^{4}$

2Dewi, W. W., \& Ibrahim, R. Kekuatan Hukum Pelekatan Sidik Jari Penghadap Oleh Notaris Pada Minuta Akta. Acta Comitas: Jurnal Hukum Kenotariatan, 5(3), 436-445. h.440 doi: https://doi.org/10.24843/AC.2020.v05.i03.p01

${ }_{3}^{3}$ Jerat Hukum bagi Notaris yang Memalsukan Akta Autentik https://www.hukumonline.com/klinik/detail/ulasan/lt5c5a568ab332f/jerat-hukum-bagiNotaris-yang-memalsukan-akta-autentik.(Diakses 19 Februari 2019).

${ }_{4}^{4}$ Hendra, R. (2012). Tanggungjawab Notaris Terhadap Akta Otentik Yang Penghadapnya Mempergunakan Identitas Palsu di Kota Pekanbaru. Jurnal Ilmu Hukum, 3(1). h.8 https://jih.ejournal.unri.ac.id/index.php/JIH/article/view/1029 
Pasal 1338 KUHPer menentukan "Semua persetujuan yang dibuat sesuai dengan undang-undang berlaku sebagai undang-undang bagi mereka yang membuatnya, persetujuan itu tidak dapat ditarik kembali selain dengan kesepakatan kedua belah pihak, atau karena alasan-alasan yang ditentukan oleh undang-undang persetujuan harus dilaksanakan dengan itikad baik". Dapat diartikan bahwa untuk serta pelaksanaan pada perikatannya wajib mematuhi makna persetujuan atas keyakinan yang baik oleh pihak-pihak.

Bila nantinya ditemukan tampak itikad tak jujur diantara salah satu individu yang melakukan pengikatan maupun pembuatan serta dalam pelaksanaannya maka yang beritikad patuh wajib mendapatkan perlindungan hukum. Pernyataan diatas maka penghadap yang hadir ke Notaris untuk membuat akta maka harus dilindungi dengan undang-undang. Upaya perlindungan hukum terhadap penghadap diatur pada ketentuan-ketentuan sanksi dalam Pasal 16 ayat (11) UUJN yang mengatur sanksi dapat diperkenankan Notaris yang membuat pelanggaran atas ketentuan pada UUJN. Berdasarkan penjelasan tersebut maka pada UUJN tidak membentuk sanksi pidana terlibat juga pada sanksi pidana Notaris yang membuat data palsu pada akta otentik, oleh karena itu dapat dikatakan UUJN tidak adanya aturan mengenai sanksi pidana kepada Notaris yang telah melanggar UUJN.

Berdasarkan hal tersebut maka diangkat permasalahan yaitu bagaimana pengaturan tanggung jawab Notaris yang melakukan pelanggaran dalam menjalankan jabatannya serta bagaimana perlindungan hukum yang diperoleh penghadap atas pemalsuan data yang dilakukan Notaris.

Penelitian ini ditujukan untuk memberikan pemahaman terkait pengaturan tanggung jawab Notaris yang melakukan pelanggaran dalam menjalankan jabatannya dan mengetahui perlindungan hukum yang diperoleh penghadap atas pemalsuan data yang dilakukan Notaris.

Berkaitan dengan orisinalitas terhadap penulisan ini, berikut peneliti uraikan beberapa penelitian terdahulu yang memiliki tema permasalahan hukum sejenis. Nur Arini dengan judul "Tanggung Jawab Notaris Atas Keterangan Palsu Yang Disampaikan Penghadap Dalam Akta Pendirian Perseroan Terbatas membahas tentang persoalan atas keterangan palsu yang dilakukan penghadap"5, selanjutnya Anita Ratna Sari melalui judul "Tanggung Jawab Notaris dalam pembuatan Akta Perjanjian Kredit dengan menggunakan Surat Palsu (Studi Kasus Putusan Pengadilan Negeri Jakarta Barat Nomor 952/PID. B/2019/PN. JKT. BRT.) mengkaji persoalan tentang pembuatan akta perjanjian kredit dengan surat palsu". ${ }^{6}$

${ }^{5}$ Aini, N., \& Simanjuntak, Y. N. (2019). Tanggung Jawab Notaris Atas Keterangan Palsu Yang Disampaikan Penghadap Dalam Akta Pendirian Perseroan. Jurnal Komunikasi Hukum, 5(2), 105116. http:/ / repository.ubaya.ac.id/36576/.

${ }^{6}$ Sari, A. R. (2020). Tanggung Jawab Notaris dalam pembuatan Akta Perjanjian Kredit dengan menggunakan Surat Palsu (Studi Kasus Putusan Pengadilan Negeri Jakarta Barat Nomor 952/PID. B/2019/PN. JKT. BRT.). Indonesian Notary, 2(2). http://notary.ui.ac.id/index.php/home/article/view/813. 
Berdasarkan beberapa penelitian yang diuraikan sebelumnya, maka dapat dipahami bahwa terdapat perbedaan pada objek pengkajian dalam penulisan ini yang secara khusus menelaah persoalan hukum dari keterangan palsu yang dilakukan para penghadap sehingga penelitian ini mempunyai suatu kebaharuan gagasan dan urgensi untuk dilakukan hal ini agar penghadap yang hadir ke Notaris untuk membuat akta dapat dilindungi dengan undang-undang agar tidak terjadinya pelangaran terhadap hak penghadap.

\section{Metode Penelitian}

Metode penelitian ini ialah hukum normatif menelaah persoalan norma yang terjadi yaitu suatu kekosongan norma tidak diaturnya mengenai sanksi pidana serta bentuk perlindungan hukum penghadap pada pembuatan akta. Penelitian menggunakan pendekatan perundang-undangan serta pendekatan fakta. Penelitian ini memuat sumber-sumber yaitu hukum bahan hukum primer, sekunder serta tersier. Pendekatan penelitian dilakukan melalui pendekatan konseptual yang menganalisa konsep penyelenggaraan pelanggaran oleh Notaris dan pendekatan peraturan perundangundangan yang diperlukan dalam menelaah permasalahan hukum yang diangkat dengan merujuk pada ketentuan hukum. ${ }^{7}$ Dalam penelitian ini teknik studi dokumen digunakan sebagai pengumpulan pada bahan hukum, kemudian terkait teknik analisis data memakai analisis kualitatif ialah suatu metode yang memiliki sifat deskriptif analisis yaitu suatu kegiatan tentu menentukan definisi pengaturan hukum yang nantinya digunakan untuk menuntaskan masalah topik pada penelitian.

\section{Hasil Dan Pembahasan}

\subsection{Pertanggungjawaban Notaris Terhadap Akta Otentik Yang Dibuat Dengan Keterangan Palsu}

Definisi otentik ini memiliki kekuatan pembuktian sempurna, siapa pun yang terlibat pada akta, semasih tidak bisa dibenarkan kebenarannya sebaliknya bersandarkan putusan pengadilan yang memiliki kekuatan hukum tetap. Terdapat beberapa syaratsyarat formal dari akta otentik ialah akta dibuat dalam struktur berdasarkan aturan perundang-undangan, diselenggarakan dengan di hadapan Pejabat Umum dan memiliki kewenagan untuk akta otentik dimana akta itu dibuat. Adami Chazami memastikan kejahatan pada tindak pidana pemalsuan merupakan tindak pidana yang memuat faktor ketidakbenaran pada objek yang sebenarnya berbeda dengan kebenarannya. ${ }^{8}$

Perbuatan Notaris melakukan tindak pidana pemalsuan pada akta otentik yang dibuatnya tidak dapat dibenarkan dan pastinya akan merugikan kepentingan pihak mengenai akta otentik, sebab pihak yang terkait atas akta Notaris yang merasa hakhaknya dirugikan akibat Notaris yang melanggar tindak pidana pemalsuan tentunya berhak untuk melakukan suatu upaya hukum terkait. Pihak yang dirugikan boleh melakukan gugatan ke pengadilan negeri demi memintakan akta otentik untuk dibatalkan.

7Soekanto, S., \& Mamudji, S. (2001). Penelitian hukum normatif (Suatu tinjauan singkat). Jakarta : Raja Grafindo Persada. h. 23

${ }^{8}$ Chazami, A. (2001). Kejahatan Terhadap Pemalsuan. Jakarta:PT Raja Grafindo Persada.h.99 
Hal pembatalan akta otentik juga bisa dilakukan Notaris jika penghadap mengetahui ada kelalaian yang dituangkan pada akta, sehingga bisa membuat kebingungan atas kesepakatan penghadap hingga akta bisa dibatalkan Notaris. Apabila Notaris melalukan pemalsuan akta atau Notaris ikut membuat pemalsuan surat yang dapat didefinisikan sebagai perlakuan tindak pidana sehingga secara yuridis tak bisa ditolerir bersandarkan pada ketentuan pidana melainkkan atas Peraturan KUH Perdata dan pada UUJN.

Ketika suatu akta yang dibuat oleh Notaris mengandung suatu cacat hukum ataupun mengandung suatu tindak pidana pemalsuan, maka berdasarkan dakwaan oleh pihak yang terkait dengan akta, tentunya akta Notaris dapat dimintakan untuk dibatalkan ke pengadilan negeri, dan berdasarkan keputusan yang sudah berkekuatan hukum tetap yang ditetapkan oleh pengadilan negeri tersebut dinyatakan sebagai akta yang tidak mengikat bagi para pihak yang membuatnya. ${ }^{9}$ Kepada Notaris yang bersangkutan tentunya dapat dimintakan pertanggungjawaban secara administratif, perdata maupun secara pidana. Adapun sanksi Notaris yang melakukan pemalsuan data dalam pembuatan akta otentik, kemudian sanksi yang diberikan Notaris ialah:

a. sanksi menurut hukum KUH Perdata

b. sanksi menurut hukum KUH Pidana

c. sanksi administratif atau Kode Etik Notaris

Sanksi administrasi tersebut diberikan bila tidak melaksanakan kewajiban dan melakukan larangan jabatan ataupun bila melakukan suatu pelanggaran maupun penyimpangan terhadap kewajiban jabatan serta larangan jabatan, sanksi administratif dibedakan atas:

1. sanksi reparatif yaitu digunakannya sanksi dengan tujuan untuk memperbaiki atas suatu tindakan pelanggaran terhadap aturan hukum.

2. sanksi punitif yaitu suatu beban tambahan dan suatu tindakan yang dapat memberi rasa takut terhadap pelanggarnya dalam hal ini dapat berupa teguran secara tegas.

3. sanksi regresif yaitu diartikan sanksi sebagai suatu resiko atau akibat dari ketidakpatuhan terhadap suatu aturan hukum. ${ }^{10}$

Ketidakpatuhan terhadap sesuatu hal yang menjadi kewajiban yang telah termuat diperaturan perundang-undangan dapat menimbulkan ketidaksesuaian yang tidak diharapkan dari suatu peraturan perundang-undangan tersebut. Sanksi digunakan untuk penegakan suatu aturan yang berisi suatu kewajiban. Sanksi sebagai suatu paksaan dengan tujuan untuk memberi kesadaran terhadap pihak yang melakukan pelanggaran bahwa tindakan yang dilakukannya telah menyimpang dari kaidah hukum yang berlaku sehingga keselarasan suatu aturan hukum akan dapat terjaga, disamping itu dapat pula memberi kesadaran serta efek jera kepada pelanggarnya. Sanksi yang diberikan kepada Notaris berguna sebagai bentuk memberikan kesadaran

\footnotetext{
9 Sandro, E., \& Tjempaka, T. (2019). Tanggung Jawab Notaris Atas Akta Autentik Yang Dibuatnya DenganSurat Kuasa Yang Cacat Hukum Serta Tidak Dibacakannya Akta Tersebut (Studi Kasus Putusan Nomor 25/PDT. G/2017/PN. CBI). Jurnal Hukum Adigama, 2(2), 340-365. h.347, http://journal.untar.ac.id/index.php/adigama/article/view/6536

${ }^{10}$ Adjie, H. (2013). Menjalin pemikiran-pendapattentang kenotariatan:kumpulan tulisan. Bandung: PT Citra Aditya Bakti.h.116
} 
terhadap Notaris bahwa telah melakukan suatu penyimpangan dalam melaksanakan tugas jabatannya dan agar Notaris mentaati segala aturan yang telah ditentukan dan ditetapkan didalam peraturan perundang-undangan. Pemberian sanksi juga memberi perlindungan kepada masyarakat yang menggunakan jasanya agar terhindar dari halhal yang dapat merugikannya.

\subsection{Perlindungan Hukum Bagi Penghadap Atas Keterangan Palsu Pada Pembuatan Akta}

Notaris membuat akta wajib memuat keterangan berdasarkan atas keinginan atau kehendak dari pihak yang datang menghadap dirinya. Apabila terjadi suatu permasalahan hukum mengenai akta yang dibuat Notaris di kemudian hari, maka Notaris secara moril wajib untuk bertanggung jawab dan pihak-pihak yang menganggap dirugikan juga bisa menggugat pertanggungjawaban kepada Notaris tersebut. Dalam hal Notaris terbukti melakukan suatu kesalahan terkait dengan akta yang dibuatnya, maka Notaris juga dapat dimintakan pertanggungjawaban secara perdata, administrative dan secara pidana.

Dari pertanggungjawaban secara perdata bagi Notaris yang melakukan perbuatan melawan hukum adalah Notaris wajib mempertanggung jawabkan perbuatannya dengan dijatuhi sanksi perdata berupa penggantian biaya ganti rugi kepada pihak yang dirugikan atas perbuatan melawan hukum yang dilakukan oleh Notaris yang bersangkutan. Namun sebelum Notaris dijatuhi sanksi perdata maka terlebih dahulu harus dapat dibuktikan bahwa telah terjadi adanya kerugian yang ditimbulkan dari perbuatan melawan hukum Notaris terhadap para pihak, dan antara kerugian yang diderita dan perbuatan melawan hukum dari Notaris terdapat hubungan kausal, serta perbuatan melawan hukum atau kelalaian notaris tersebut disebabkan kesalahan yang dapat dipertanggungjawabkan oleh notaris yang bersangkutan.

Secara administrasi ada 5 jenis administrasi yang diberikan apabila seorang Notaris melanggar ketentuan UUJN yaitu peringatan lisan, peringatan tertulis, pemberhentian sementara, pemberhentian dengan hormat dan pemberhentian dengan tidak hormat, itu berlaku secara berjenjang mulai dari teguran lisan sampai dengan pemberhentian dengan tidak hormat. ${ }^{11}$

Dalam hukum pidana tanggungjawab Notaris atas akta yang dibuatnya tidak diatur dalam UUJN namun tanggungjawab Notaris secara pidana dikenakan apabila Notaris melakukan perbuatan pidana. UUJN hanya mengatur sanksi atas pelanggaran yang dilakukan oleh Notaris terhadap UUJN sanksi tersebut dapat berupa akta yang dibuat oleh Notaris tidak memiliki kekuatan otentik atau hanya mempunyai kekuatan sebagai akta di bawah tangan. Terhadap Notarisnya sendiri dapat diberikan sanksi yang berupa teguran hingga pemberhentian dengan tidak hormat. Untuk dapat memintakan pertanggungjawaban tersebut maka sebelum adanya putusan pengadilan yang tetap, akta Notaris wajib dikatatakan menjadi akta yang sah serta mengikat (presumtio justea causa). ${ }^{12}$

\footnotetext{
${ }^{11}$ Ibid, h.134

12Wulandari, A. A. D. (2018). Tanggung Jawab Notaris Akibat Batalnya Akta Perjanjian Pengikatan Jual Beli Tanah Karena Cacat Hukum. Acta Comitas: Jurnal Hukum Kenotariatan, 3(3), 436-445. h.442, doi: https:// doi.org/10.24843/AC.2018.v03.i03.p04
} 
Kekosongan hukum terkait dengan tidak diaturnya secara eksplisit mengenai tindak pidana yang dibuat mengarah KUH Pidana dengan demikian Notaris yang dihentikan dengan tak hormat dikarenakan pelanggaran Notaris menyinggung pidana penjara bersandarkan putusan pengadilan yang memiliki kekuatan hukum yang tetap sebagai akibat melakukan tindak pidana pemalsuan pada akta yang dibuatnya dengan hukuman 5 tahun penjara ataupun lebih sehingga protokol Notarisnya dikerjakan oleh Notaris lain yang telah dipilih oleh Menteri Hukum \& HAM atas dasar dari Majelis Pengawasan Pusat. Selain itu Notaris juga dapat digugat ganti rugi sesuai dengan Pasal 1365 KUH Perdata apabila pelanggaran atau kesalahan yang dilakukan Notaris mengakibatkan suatu akta menjadi tidak otentik dan terdegradasi menjadi akta di bawah tangan. Inilah bentuk perlindungan yang diberikan kepada penghadap jika seseorang Notaris tidak melaksanakan tugas dan kewajibannya.

Ketentuan Pasal 55 ayat (1) KUH Pidana dapat digunakan dalam hal suatu akta Notaris dibuat menggunakan data palsu, jika Notaris mengetahui bahwa data tersebut palsu dan Notaris masih bersedia membuatkan aktanya, maka Notaris yang bersangkutan dapat dinyatakan sebagai medepleyer hal ini dikarenakan Notaris yang turut serta dalam pembuatan akta serta memalsukan data. Apabila penggunaan data palsu untuk membuat akta Notaris, dilakukan dengan sengaja, maka Notaris dapat dimintakan pertanggungjawaban berdasarkan Pasal 266 ayat (2) KUHP yang menentukan "barang siapa dengan sengaja memakai surat palsu yang isinya tidak sejati atau dipalsukan seolah-olah benar dan tidak dipalsukan, jika pemalsuan surat itu dapat menimbulkan kerugian" selanjutnya Notaris dapat dimintakan pertanggungjawaban pidana berdasarkan ketentuan Pasal 263 ayat (2) menentukan "memakai data palsu yang diberikan oleh penghadap sebagai dasar pembuatan akta otentik".

Namun, jika Notaris tidak mengetahui kepalsuan data yang digunakan untuk membuat akta, maka Notaris hanya dianggap lalai atau tidak cermat dalam melakukan kewenangannya. Di sini penghadap yang memalsukan data, sedangkan Notaris menggunakan data palsu ini untuk akta otentik, apabila penggunaan data palsu ini tidak sengaja dilakukan Notaris karena Notaris tidak mengetahui kepalsuan data tersebut pertanggungjawaban yang dapat diberikan kepada Notaris adalah pertanggungjawaban perdata, sebaliknya apabila Notaris tahu kepalsuan data tersebut dan dengan sengaja menggunakannya maka Notaris yang bersangkutan dapat dikenakan pertanggungjawaban pidana. ${ }^{13}$ Teori pertanggungjawaban pidana menurut Moeljatno menyatakan "terjadinya tindak pidana seseorang akan dipertanggungjawabkan atas tindakan-tindakan tersebut, apabila tindakan tersebut memenuhi unsur melawan hukum serta unsur tidak ada alasan pembenar atau unsur peniadaan sifat melawan hukum untuk pidana yang dilakukannya". ${ }^{14}$

13Siahaan, K. (2019). Kedudukan Hukum Akta NotarisSebagai Alat Bukti Pada Tindak Pidana Pemalsuan Surat Dalam Proses Peradilan Pidana. Recital Review, 1(2), 72-88. h.78, https://online-journal.unja.ac.id/RR/article/view/7455

14Moeljatno. (2003). Perbuatan pidana dan Pertanggungjawaban Dalam Hukum Pidana. Jakarta: Bina Aksara. h.49 
Ditinjau menurut Moeljatno "hanya seorang yang mampu bertanggungjawab yang dapat dipertanggungjawabkan atas perbuatannya" yang dalam hal ini Notaris merupakan orang mampu bertanggung jawab terkait perbuatannya selanjutnya bila ditinjau dan adanya unsur kesalahan, apabila pembuatan akta dengan data palsu tidak diketahui oleh Notaris, maka dalam hal ini tidak ada unsur kesalahan. Sebaliknya bila Notaris dengan sengaja membuat akta padahal diketahui bahwa data yang digunakan palsu, maka pada kondisi ini Notaris wajib bertanggungjawab secara pidana. ${ }^{15}$ Tanggungjawab Notaris terkait adanya unsur-unsur kesalahan wajib diperiksa terlebih dahulu apakah Notaris memang dengan sengaja membuat akta otentik dengan data palsu mengenai hal itu hukum pidana dapat dijatuhkan kepada Notaris yang dengan sengaja membuat akta otentik dengan menggunakan data palsu. ${ }^{16}$ Notaris juga dapat digugat ganti rugi apabila pelanggaran atau kesalahan yang dilakukan Notaris mengakibatkan suatu akta menjadi tidak otentik dan terdegradasi menjadi akta di bawah tangan. Inilah bentuk perlindungan yang diberikan kepada penghadap jika seseorang Notaris tidak melaksanakan tugas dan kewajibannya.

\section{Kesimpulan}

Akibat hukum akta Notaris mengandung suatu tindak pidana pemalsuan, maka akta Notaris dapat dimintakan untuk dibatalkan dan berdasarkan keputusan yang sudah berkuatan hukum tetap yang ditetapkan oleh pengadilan negeri tersebut maka akta Notaris dapat dibatalkan dan dinyatakan sebagai akta yang tidak mengikat bagi para pihak yang membuatnya. Kepada Notaris yang bersangkutan tentunya dapat dimintakan pertanggungjawaban secara administratif, perdata maupun secara pidana. Adapun sanksi Notaris melakukan pemalsuan data dalam pembuatan akta otentik kemudian sanksi yang diberikan Notaris ialah sanksi administratif atau Kode Etik Notaris, sanksi menurut hukum KUH Perdata, sanksi menurut KUH Pidana. Notaris juga dapat digugat ganti rugi apabila pelanggaran atau kesalahan yang dilakukan Notaris mengakibatkan suatu akta menjadi tidak otentik dan terdegradasi menjadi akta di bawah tangan. Pembuatan akta otentik apabila penggunaan data palsu ini tidak sengaja dilakukan Notaris karena Notaris tidak mengetahui kepalsuan data tersebut pertanggungjawaban yang dapat diberikan kepada Notaris adalah pertanggungjawaban perdata, sebaliknya apabila Notaris tahu kepalsuan data tersebut dan dengan sengaja menggunakannya maka Notaris yang bersangkutan dapat diberikan pertanggungjawaban secara pidana.

15Ibid
16Enggarwati, I. D. (2015). Pertanggungjawaban Pidana Dan Perlindungan Hukum Bagi Notaris
Yang Diperiksa Oleh Penyidik Dalam Tindak Pidana Keterangan Palsu Pada Akta Otentik.
$\begin{array}{lllll}\text { Kumpulan } & \text { Jurnal } & \text { Mahasiswa } & \text { Fakultas } & \text { Hukum. }\end{array}$ http:/ /hukum.studentjournal.ub.ac.id/index.php/hukum/article/view/1394. h.10 


\section{Daftar Pustaka}

\section{Buku}

Adjie, H. (2013). Menjalin pemikiran-pendapat tentang kenotariatan: kumpulan tulisan. Bandung : PT Citra Aditya Bakti.

Chazami, A. (2001). Kejahatan Terhadap Pemalsuan. Jakarta : PT Raja Grafindo Persada.

Soekanto, S., \& Mamudji, S. (2001). Penelitian hukum normatif (Suatu tinjauan singkat). Jakarta : Raja Grafindo Persada.

Moeljatno (2003). Perbuatan pidana dan Pertanggungjawaban Dalam Hukum Pidana. Jakarta : Bina Aksara.

\section{Jurnal}

Aini, N., \& Simanjuntak, Y. N. (2019). Tanggung Jawab Notaris Atas Keterangan Palsu Yang Disampaikan Penghadap Dalam Akta Pendirian Perseroan. Jurnal Komunikasi Hukum, 5(2), 105-116. http://repository.ubaya.ac.id/36576/.

Dewi, W. W., \& Ibrahim, R. Kekuatan Hukum Pelekatan Sidik Jari Penghadap Oleh Notaris Pada Minuta Akta. Acta Comitas: Jurnal Hukum Kenotariatan , 5(3), 436445. doi: https://doi.org/10.24843/AC.2020.v05.i03.p01.

Enggarwati, I. D. (2015). Pertanggungjawaban Pidana Dan Perlindungan Hukum Bagi Notaris Yang Diperiksa Oleh Penyidik Dalam Tindak Pidana Keterangan Palsu Pada Akta Otentik. Kumpulan Jurnal Mahasiswa Fakultas Hukum,2(1). http://hukum. studentjournal.ub.ac.id/index.php/hukum/article/view/1394.

Hendra, R. (2012). Tanggungjawab Notaris Terhadap Akta Otentik Yang Penghadapnya Mempergunakan Identitas Palsu di Kota Pekanbaru. Jurnal Ilmu Hukum, 3(1). https://jih.ejournal.unri.ac.id/index.php/JIH/article/view/1029.

Rositawati, D., Utama, I. M. A., \& Kasih, D. P. D. (2017). Penyimpanan Protokol Notaris secara Elektronik dalam Kaitan Cyber Notary. Acta Comitas: Jurnal Hukum Kenotariatan, 2(2), 172-182. doi: https://doi.org/10.24843/AC.2017.v02.i02.p01.

Sandro, E., \& Tjempaka, T. (2019). Tanggung Jawab Notaris Atas Akta Autentik Yang Dibuatnya Dengan Surat Kuasa Yang Cacat Hukum Serta Tidak Dibacakannya Akta Tersebut (Studi Kasus Putusan Nomor 25/PDT. G/2017/PN. CBI). Jurnal Hukum Adigama, 2(2), 340-365. http://journal.untar.ac.id/index.php/adigama/article/view/6536.

Sari, A. R. (2020). Tanggung Jawab Notaris dalam pembuatan Akta Perjanjian Kredit dengan menggunakan Surat Palsu (Studi Kasus Putusan Pengadilan Negeri Jakarta Barat Nomor 952/PID. B/2019/PN. JKT. BRT.). Indonesian Notary, 2(2). http://notary.ui.ac.id/index.php/home/article/view/813. 
Siahaan, K. (2019). Kedudukan Hukum Akta Notaris Sebagai Alat Bukti Pada Tindak Pidana Pemalsuan Surat Dalam Proses Peradilan Pidana. Recital Review, 1(2), 7288. https://online-journal.unja.ac.id/RR/article/view/7455.

Triwahyuni, A. D. (2020). Kewajiban Dan Tanggung Jawab Notaris Sebagai Pejabat Umum. Acta Comitas: Jurnal Hukum Kenotariatan, 5(1), 1-10. doi: https://doi.org/10.24843/AC.2020.v05.i01.p01.

Wulandari, A. A. D. (2018). Tanggung Jawab Notaris Akibat Batalnya Akta Perjanjian Pengikatan Jual Beli Tanah Karena Cacat Hukum. Acta Comitas: Jurnal Hukum Kenotariatan, 3(3), 436-445. doi: https://doi.org/10.24843/AC.2018.v03.i03.p04.

\section{Peraturan Perundang-undangan}

Kitab Undang-Undang Hukum Perdata.

Kitab Undang-Undang Hukum Pidana.

Indonesia, Undang-Undang Republik Indonesia Nomor 2 Tahun 2014 tentang Perubahan Atas Undang-Undang Nomor 30 Tahun 2004 tentang Jabatan Notaris, Lembaran Negara Republik Indonesia Tahun 2014 Nomor 3, Tambahan Lembaran Negara Republik Indonesia Nomor 5491.

\section{Website}

Jerat Hukum bagi Notaris yang Memalsukan Akta Autentik https://www.hukumonline.com/klinik/detail/ulasan/lt5c5a568ab332f/jerathukum-bagi-Notaris-yang-memalsukan-akta-autentik. (Diakses 19 Februari 2019). 